Program för kultur

Sveriges ordförandeskap 2018

(1I) Nordiska ministerrådet 


\section{Program för kultur}

Sveriges ordförandeskap 2018 i Nordiska ministerrådet

ANP 2017:790

ISBN 978-92-893-5301-4 (PRINT)

ISBN 978-92-893-5302-1 (PDF)

ISBN 978-92-893-5303-8 (EPUB)

http://dx.doi.org/10.6027/ANP2017-790

(c) Nordiska ministerrådet 2017

Layout: Louise Jeppesen

Omslagsfoto: Folio

\section{Det nordiska samarbetet}

Det nordiska samarbetet är ett av världens mest omfattande regionala samarbeten. Det omfattar Danmark, Finland, Island, Norge och Sverige samt Färöarna, Grönland och Åland.

Det nordiska samarbetet är politiskt, ekonomiskt och kulturellt förankrat och en viktig del av europeiskt och internationellt samarbete. Den nordiska gemenskapen arbetar för ett starkt Norden i ett starkt Europa.

Det nordiska samarbetet vill styrka nordiska och regionala intressen och värderingar i en global omvärld. Gemensamma värderingar länderna emellan bidrar till att stärka Nordens ställning som en av världens mest innovativa och konkurrenskraftiga regioner.

\section{Nordiska ministerrådet \\ Nordens Hus \\ Ved Stranden 18 \\ 1061 København K \\ www.norden.org}

Ladda ner nordiska publikationer: www.norden.org/nordpub 


\section{Program för kultur}

Sveriges ordförandeskap 2018

i Nordiska ministerrådet

04 Förord

06 Det hållbara Norden

08 Det kreativa Norden

09 Det interkulturella Norden

10 Det unga Norden

11 Det digitala Norden

12 Ett nordiskt kultursamarbete relevant för alla nivåer 


\section{Förord}

Det övergripande temat för det svenska ordförandeskapet i Nordiska ministerrådet 2018 är Ett inkluderande, innovativt och tryggt Norden. Jag hoppas att vi under året kan bidra till att visa kultursektorns avgörande roll i förverkligandet av denna vision. Kultur för oss samman, stimulerar till debatt och bidrar till förnyelse och nytänkande, också inom andra samhällssektorer. Kulturen bidrar till ett mer öppet Norden.

Den strategi som de nordiska kulturministrarna har arbetat under sedan 2013 reviderades under 2016 och är fortfarande högst relevant. Därför utgår det svenska ordförandeskapet från dess fem teman: det Hållbara, Kreativa, Interkulturella, Unga och Digitala Norden.

Social, ekonomisk och miljömässig hållbarhet är ett övergripande tema för allt vårt arbete. Agenda 2030 tydliggör hur alla sektorer på sitt sätt bidrar till hållbarheten, och Norden ska vara en förebild $\mathrm{i}$ implementeringen av denna. Vi måste inte alltid vara bäst i världen, men vi ska vara bäst för världen. Främjandet av nordiska design- och arkitekturlösningar för hållbarhet är bra för nordiska aktörer och för bilden av Norden internationellt - men bidrar också till att sprida goda idéer som kan vara till nytta för resten av världen.

För mig som kultur- och demokratiminister står yttrandefriheten alltid $\mathrm{i}$ centrum. Kulturen ska vara en dynamisk, utmanande och obunden kraft med yttrandefriheten som grund. I dag står yttrandefriheten inför betydande utmaningar, i världen i stort, men även i Norden.

Hur kan vi säkra de fri- och rättigheter som vi i Norden har kämpat hårt för och där yttrandefriheten är en av de mest grundläggande? Hur ska vi föra öppna samtal om vilken framtid vi vill ha? På vilka sätt kan vi förstå varandra när skillnaderna i medieanvändning bidrar till polarisering av åsikter och verklighetsuppfattningar? Hur kan människor känna samhörighet trots att man lever sitt liv på olika sätt? Detta är utmaningar som vi vill fokusera på under vårt ordförandeskap. Fristäder för förföljda konstnärer, ungas nyhetskonsumtion, kulturens roll för språkrevitalisering och kulturskolans betydelse för ensamkom- 


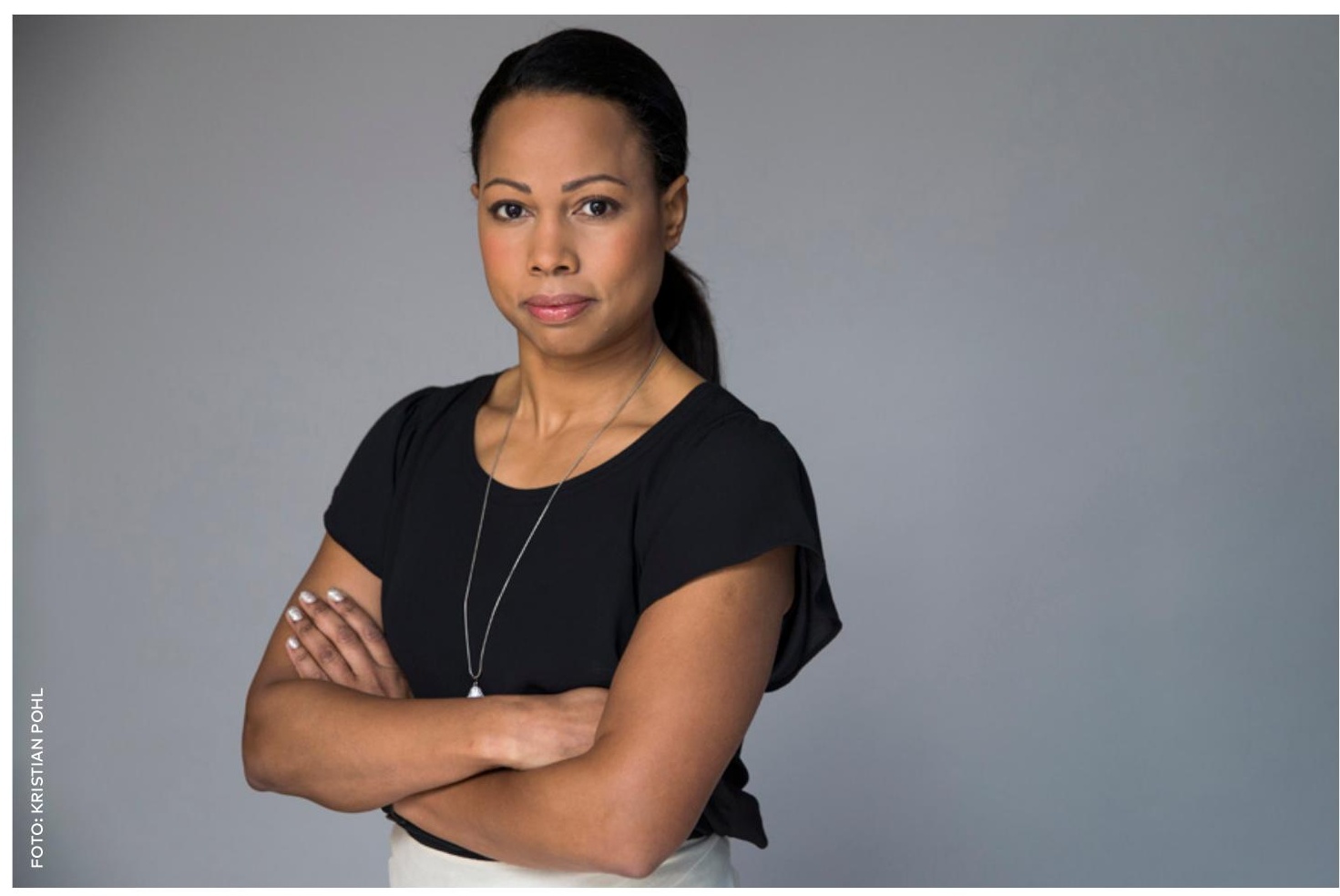

mande och nyanlända barn och unga är exempel på frågor som vi vill lyfta.

I en osäker värld är det nordiska samarbetet viktigare än någonsin. Även om Norden är en internationell förebild i flera avseenden måste vi ständigt pröva och ompröva våra vägval och även vår roll i förhållande till resten av världen.

De nordiska länderna måste sinsemellan ha en ständigt pågående dialog och ett levande utbyte. Det är av största vikt att resultatet av det nordiska samarbetet kommer människor till del såväl nationellt som regionalt och lokalt. Jag ser mycket fram emot det nordiska kulturpolitiska toppmöte vi arrangerar tillsammans med Sveriges Kommuner och Landsting, Region Skåne och

Nordisk kulturfond i Malmö i maj 2018.

Min förhoppning är att Sveriges ordförandeskapsår ska bli ett år av inspiration, eftertanke och skaparglädje i ett inkluderande, innovativt och tryggt Norden!

Alice Bah Kuhnke Kultur- och demokratiminister 


\section{Det hållbara Norden}

I och med antagandet av Agenda 2030 har hela världen ett gemensamt ramverk för hållbar utveckling, även om utmaningarna ser olika ut i olika delar av världen. De nordiska länderna står i mångt och mycket inför liknande utmaningar - och de är stora. Samtidigt har Norden potential att vara en förebild för resten av världen i implementeringen av Agenda 2030 och ett samnordiskt program för denna implementering har etablerats. Bland de 17 globala målen finns få direkta referenser till kulturen, men det är upp till kulturpolitiken att visa vilken relevans kulturen ändå har för hållbar utveckling. Dess roll för yttrandefrihet, att tänka i nya banor, för förståelse, sammanhållning och kritisk debatt behöver lyftas.

En tydlig roll för kulturen återfinns i det mål som det samnordiska programmet har valt som sitt fokusområde - det tolfte målet om att främja hållbara konsumtions- och produktionsmönster. Kreativitet kan visa vägen - designen och arkitekturen är här av särskild betydelse. De nordiska länderna har redan framflyttade positioner vad gäller den kulturella och kreativa sektorns livskraft såväl som innovativa hållbarhetslösningar, men det finns ytterligare potential att främja de lösningar för hållbara konsumtions- och produktionsmönster som uppstår i designen och arkitekturen.

\section{Främjande av}

\section{nordiska hållbarhetslösningar}

Inom den treåriga svenska ordförandeskapssatsningen Främjande av nordiska hållbarhetslösningar kommer den nordiska plattformen för hållbar arkitektur och design, Sustainordic, att skala upp sin verksamhet betydligt. Detta sker delvis genom att lyfta goda nordiska exempel och genomföra internationella främjandeinsatser.

\section{Arkitekturkonferens}

Statens centrum för arkitektur och design tar upp traditionen att anordna en nordisk arkitekturkonferens, denna gång på temat hållbarhet, i Stockholm mellan den 31 maj och den 1 juni. Konferensen kommer att titta närmare på förhållandet mellan forskning och praktik inom nordisk arkitektur och design för att uppnå hållbara och bärkraftiga livsmiljöer. 


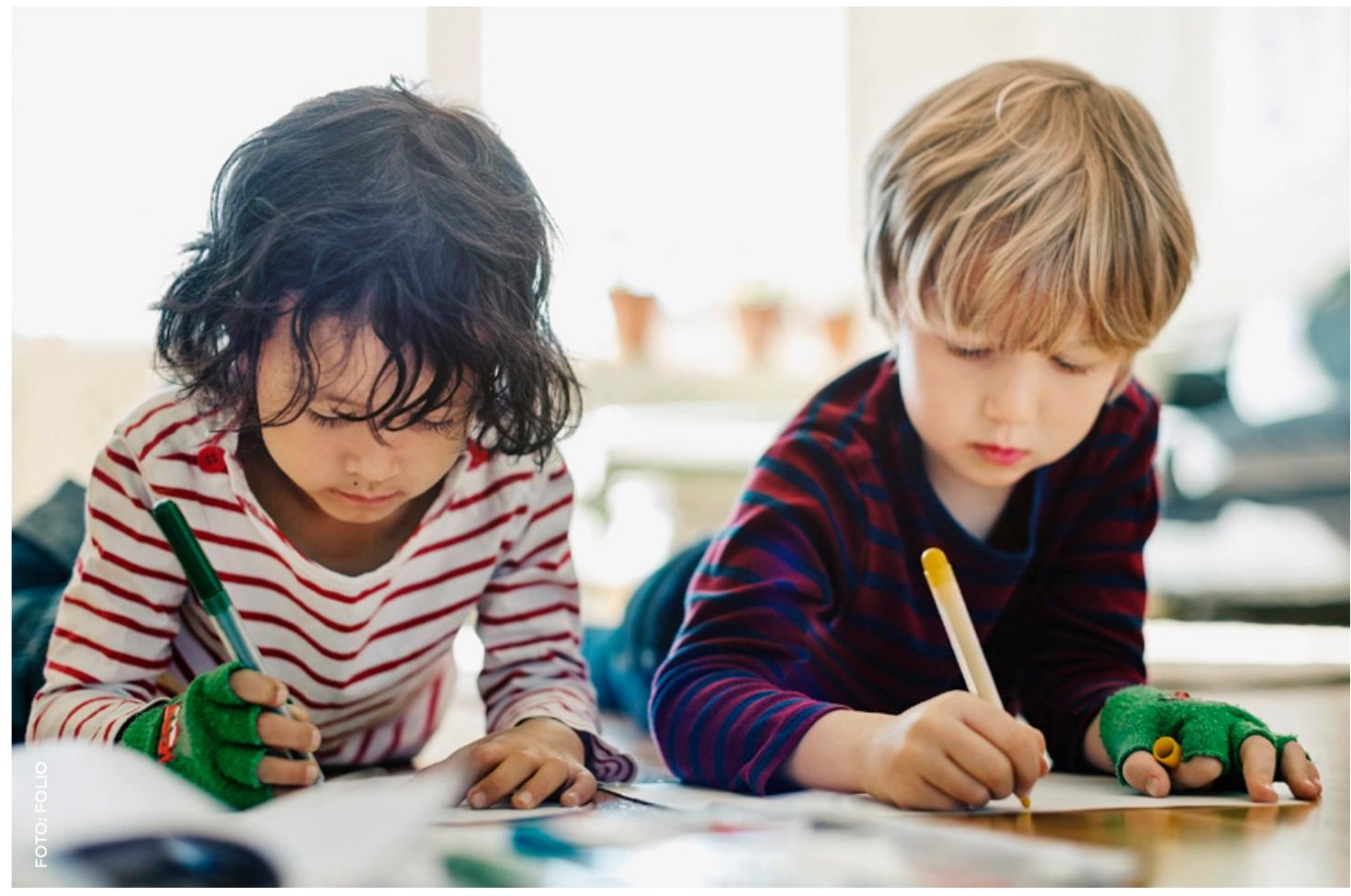

\section{Konferens om kultur och hälsa}

Kultur och hälsa är ett växande kunskapsfält i de nordiska länderna. För att bidra till ökat utbyte inom området kommer Kompetenscentrum för kultur och hälsa vid Stockholms läns landsting under en konferens i Stockholm under senvåren arrangera en dialog mellan olika vetenskapliga traditioner och professionella fält av praktiker. Fokus är på hur konst och kultur kan komplettera traditionell vård och omsorg. 


\section{Det kreativa Norden}

Att det finns en stor nyfikenhet på det som skapas i de nordiska länderna har inte minst visat sig i uppmärksamheten kring kulturfestivalen Nordic Matters på Southbank Centre i London. Iceland Dance Company, Tove Jansson, Moddi, Kim Leine, Outi Pieski och Cirkus Cirkör är några av de kulturskapare som där visat på styrkan och mångfalden hos det nordiska kulturlivet.

Under 2018 finns flera initiativ som uppmärksammar den nordiska kulturen. Kulturfestivalen Nordic Spring i Montreal, dansfestivalen Festival Nordique i Paris och New Nordic Museum i Seattle är exempel på initiativ som har uppstått utanför det nordiska kultursamarbetet. Dessutom kommer 100 års-jubileet för Ingmar Bergmans födelse att uppmärksammas på många platser runt om i världen.

Omvärldens stora intresse för nordisk kultur vittnar om att det här finns goda förutsättningar för kulturskapande. Men dessa förutsättningar kan alltid förbättras och rätten att kunna uttrycka sig fritt måste ständigt försvaras.
Ett gott klimat för professionellt kulturskapande förutsätter goda utbildningsmöjligheter, goda ekonomiska förutsättningar men även möjligheten att kunna ge uttryck för sin kreativitet utan att tystas vare sig av offentliga institutioner eller av rädsla för hot och hat. Att detta ansvar inte slutar vid våra gränser visar sig inte minst genom att Norden är den region i världen som erbjuder flest fristäder till förföljda konstnärer.

\section{Fristadskonferens}

Statens kulturråd och Malmö stad arrangerar tillsammans med ett flertal andra aktörer konferensen och expertmötet Safe Havens den 5-7 december i Malmö. Syftet är att stärka det nordiska samarbetet kring yttrandefrihetsfrågor och hotade konstnärer samt att återkoppla till det första expertmötet på temat som hölls under det förra svenska ordförandeskapet 2013. Konferensen ska sammanföra tjänstemän från de nordiska länderna med internationella experter inom fristadsområdet för att skapa nätverk och förutsättningar för att främja yttrandefriheten och fristadssystemet i ett nordiskt, europeiskt och internationellt sammanhang. 


\section{Det interkulturella Norden}

Det finns så mycket som förenar Norden att man utifrån lätt kan få en bild av ett homogent område. Men mångfalden har alltid funnits, såväl mellan som inom de nordiska länderna. Denna mångfald har blivit allt tydligare under senare år, med ökade influenser från övriga världen. Att mångfalden alltid har varit en integrerad del av Norden tydliggörs inte minst av regionens mångfasetterade kulturarv, som tydligt visar på samspelet mellan Norden och resten av världen.

I de nordiska länderna finns flera erkända nationella minoriteter och urfolk. Det finns också samhällsbärande språk som genom sin ringa storlek ändå är sårbara. De nordiska länderna är alla parter $\mathrm{i}$ Unescos konvention från 2005 om skydd för och främjande av mångfalden av kulturyttringar och har därmed åtagit sig att värna och stärka förutsättningarna för att dessa kulturyttringar ska kunna bevaras och utvecklas.

\section{Språkrevitalisering}

Flera språk i Norden talas av få personer och är sårbara. De riskerar att försvinna för alltid om insatser inte görs för att revitalisera dem. Institutet för språk och folkminnen och Sametinget i Sverige anordnar mellan den 31 maj och den 1 juni ett erfarenhetsutbyte i form av en workshop under titeln Håll språken levande! Kulturens betydelse för Nordens språkliga mångfald. Arrangemanget innehåller inslag av goda exempel på kultur för språkrevitalisering i de nordiska länderna för att inspirera och bygga kapacitet för nutid och framtid. 


\section{Det unga Norden}

Nordiska ministerrådets vision är att Norden ska vara den bästa platsen $i$ världen för barn och unga. En stor del av denna vision kan förverkligas genom kultursamarbetet, som enligt de nordiska kulturministrarnas strategi ska prioritera konst och kultur för, av och med barn och unga. Det egna skapandet är avgörande för såväl kreativitet som självförtroende under resten av livet. Att detta synsätt präglar Norden tydliggörs bland annat av att alla de nordiska länderna har någon form av offentligt finansierade musik- eller kulturskolor öppna för alla.

God tillgång till konst, kultur och det egna skapandet måste vara en självklarhet för alla barn, oavsett övriga förutsättningar. I de nordiska kulturministrarnas strategi betonas vikten av att lägga särskilt fokus på barn och unga i utsatta positioner. I detta ingår självklart ensamkommande och nyanlända barn och unga.

\section{Kulturskolan och ensamkommande och nyanlända barn och unga}

Under de senaste åren har många barn och unga sökt sig till Norden för säkerhet, inte sällan som ensamkommande. Under det svenska ordförandeskapet anordnar Kulturskolerådet ett nordiskt och estniskt projekt om ensamkommande och nyanlända barn och unga samt integration genom kulturutövande med nätverksträffar och en konferens på temat den 20-21 mars. 


\section{Det digitala Norden}

Digitaliseringen står i centrum för det övergripande svenska ordförandeskapet för Nordiska ministerrådet. Strategin för kultursamarbetet slår fast att digital förmedling är en viktig del av arbetet med att demokratisera tillgången till både kulturarv och nyproducerad konst och kultur i Norden.

Den snabba digitala utvecklingen har skapat både möjligheter och stora utmaningar för det demokratiska samtalet. Det finns på många sätt bättre förutsättningar för att uttrycka, sprida och ta del av olika åsikter, idéer och information och därigenom ifrågasätta andras ståndpunkter och bilda opinion. Samtidigt har digitaliseringen medfört ett förändrat informationsutbud och har åtföljts av ett hårdnat samtals- och debattklimat.

\section{Fokus på barn och ungas nyhetskonsumtion}

Det finns många likheter mellan de nordiska länderna i fråga om ungas medievanor, men också skillnader. I anslutning till kulturtoppmötet i Malmö 8-9 maj håller Nordicom och Statens medieråd ett arrangemang på temat ungas nyhetskonsumtion $i$ ett förändrat medielandskap. Under hösten kommer sedan en antologi på temat att ges ut. Syftet är att belysa hur barn och unga tar del av nyheter och vad de anser vara pålitliga nyhetskällor i ett alltmer fragmenterat medielandskap.

\section{Riksarkivmöte}

Riksarkivet arrangerar ett nordiskt expertseminarium under rubriken Nordisk informationsförsörjning under 400 år: mot demokrati, öppenhet och digitalisering. Till seminariet bjuds experter på digitalisering in från arkiv- och bibliotekssektorn i Norden och Baltikum för att diskutera samtida och framtida visioner, identifiera gemensamma problem och diskutera lösningar. Seminariet kommer att äga rum den 7-8 juni på Landsarkivet i Härnösand, samt vid Mediakonverteringscentrum i Fränsta. 


\section{Ett nordiskt kultursamarbete relevant för alla nivåer}

Principen om nordisk nytta är central i alla delar av det nordiska samarbetet. För att uppnå detta måste samarbetets vinster nå också bortom de närmast involverade. Impulser behövs också utifrån för att stimulera till nya initiativ och lösningar.

Det nordiska kultursamarbetet innebär många möjligheter också för regionala och lokala aktörer - möjligheter som inte alltid är kända. Flera nordiska länder har nyligen bakom sig eller står inför processer av regionalisering vad gäller kulturpolitiken. I Sverige finns sedan några år tillbaka Kultursamverkansmodellen, som innebär ett större kulturpolitiskt ansvar för regionala folkvalda.

Ett utbyte mellan lokala, regionala och nationella kulturpolitiker samt nordiska aktörer kan klargöra vilka de avgörande kulturpolitiska frågorna är - såväl innehållsligt som organisatoriskt. Vad kan aktörer i de olika länderna lära av varandra och hur kan de ta del av de möjligheter det nordiska kultursamarbetet innebär? För ett gott utbyte behöver även de riktiga förutsättning- arna i form av fakta, forskning och kunskap finnas till hands.

\section{Kulturtoppmöte}

Den 8 och 9 maj bjuder Sveriges kulturoch demokratiminister, i egenskap av ordförande i Nordiska ministerrådet för kultur, tillsammans med Sveriges Kommuner och Landsting, Region Skåne och Nordisk kulturfond in lokala, regionala och nationella kulturpolitiker samt nordiska aktörer till ett nordiskt kulturpolitiskt toppmöte i Malmö. Här kommer det att diskuteras hur aktörer på nordisk, nationell, regional och lokal nivå tillsammans kan stärka förutsättningarna för kultur i hela Norden. Inom ramen för toppmötet kommer även årets första ordinarie nordiska kulturministermöte att hållas, bland annat kring temat public service roll i det nya nordiska medielandskapet.

\section{Nordisk kulturpolitisk dag om inkludering och integration}

Kulturanalys Norden bjuder in till en nordisk kulturpolitisk dag i Stockholm den 29 januari under namnet Vem får vara med? Dagen sätter fokus på 


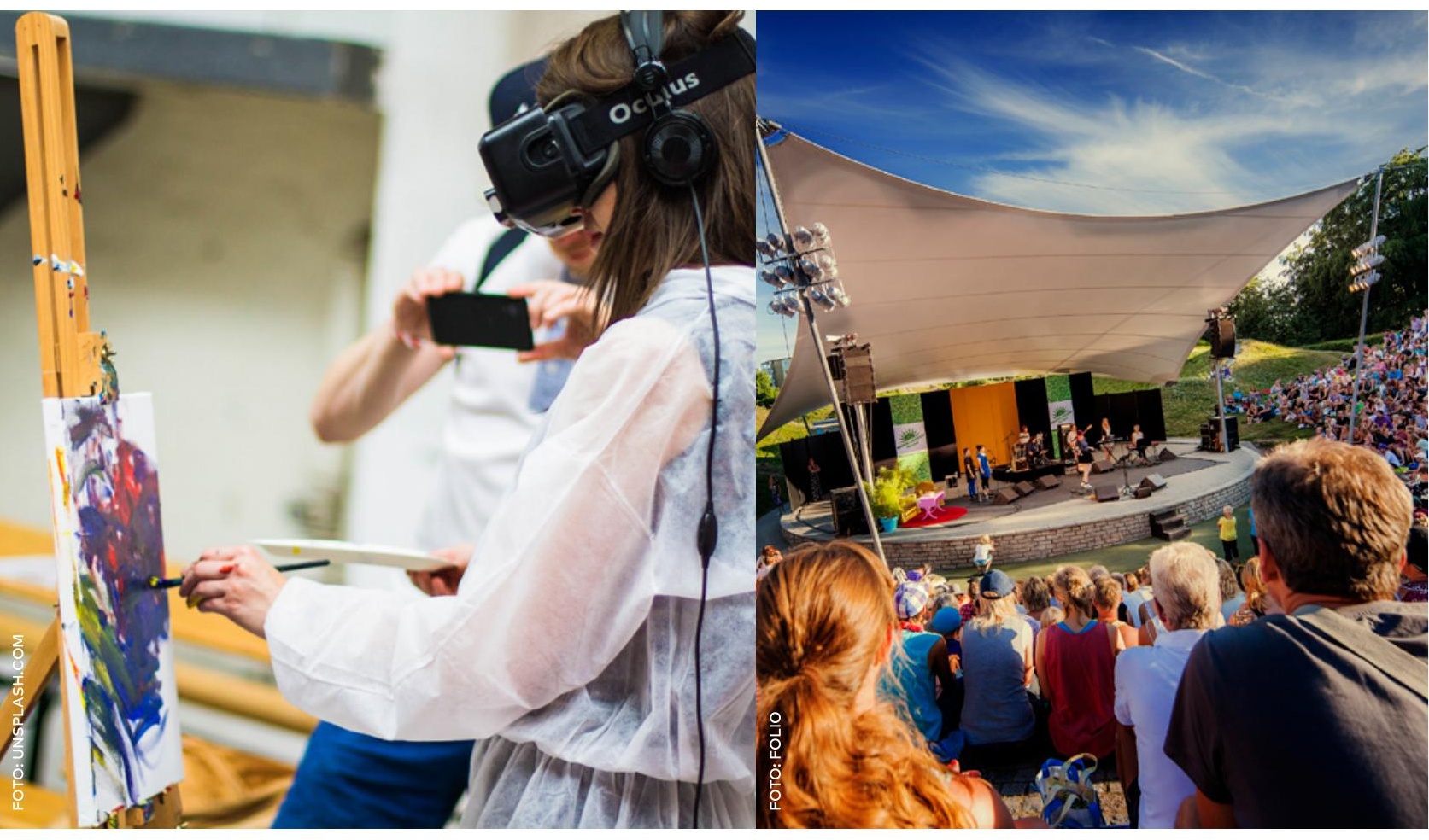

kulturens roll i ett inkluderande samhälle och kultursektorns öppenhet gentemot människor med olika bakgrunder. Avstamp för de kulturpolitiska debatterna är tre nya rapporter som jämför de nordiska länderna och belyser frågan hur inkluderande kulturlivet är i Norden. Till arrangemanget bjuds politiker, tjänstepersoner och andra aktörer inom nordisk kulturpolitik in. 
Nordiska ministerrådet

Nordens Hus

Ved Stranden 18

DK-1061 Köpenhamn K

www.norden.org

ANP 2017:790

ISBN 978-92-893-5301-4 (PRINT)

ISBN 978-92-893-5302-1 (PDF)

ISBN 978-92-893-5303-8 (EPUB) 